\title{
Kajian yuridis tentang merek terkenal dan upaya hukum terhadap pelanggarannya
}

\author{
Kevien Dicky Aldison ${ }^{1}$, Sunarjo ${ }^{2}$, Hendra Djaja ${ }^{3}$
}

${ }^{1}$ Kevien Dicky Aldison; Fakultas Hukum Universitas Merdeka Malang; Jl. Terusan Raya Dieng Nomor 6264; Malang; 65146; Jawa Timur; Indonesia.

${ }^{2}$ Sunarjo; Fakultas Hukum Universitas Merdeka Malang; Jl. Terusan Raya Dieng Nomor 62-64; Malang; 65146; Jawa Timur; Indonesia.

${ }^{3}$ Hendra Djaja; Fakultas Hukum Universitas Merdeka Malang; Jl. Terusan Raya Dieng Nomor 62-64; Malang; 65146; Jawa Timur; Indonesia.

ART ICLEINFO

Article history:

Received 2021-02-03

Received in revised form

2021-03-19

Accepted 2021-04-01

Kata kunci:

Merek; Upaya Hukum;

Pelanggaran.

Keywords:

Brand; Legal Effort; Offense.

DOI: https://doi.org/10.26905/

idjch.v12i1.5723.

\section{How to cite item:}

Aldison, K. D. Sunarjo., Djaja, Hendra. (2021). Kajian yuridis tentang merek terkenal dan upaya hukum terhadap pelanggarannya. Jurnal Cakrawala Hukum, 12(1), 41-50. doi:10.26905/idjch.v12i1.5723.

Corresponding Author:

* Sunarjo.

E-mail address: Sunarjo@unmer.ac.id.

\section{Abstrak}

Pengaturan merek secara internasional didasarkan pada Konvensi Paris dan The Agreement on Trade-Related Aspects of Intellectual Property Rights (TRIPS) sedangkan di Indonesia pengaturan mengenai merek mengalami beberapa kali perubahan di mana yang terbaru adalah Undang-Undang Nomor 20 Tahun 2016 tentang Merek dan Indikasi Geografis. Merek dapat dikatakan sebagai merek terkenal jika sudah memenuhi kriteria merek terkenal tetapi di dalam undang-undang merek Indonesia yang terbaru belum menjelaskan secara jelas mengenai kriteria merek terkenal. Penelitian ini menggunakan pendekatan yuridis normatif. Pendekatan ini fokus pada meneliti bahan-bahan kepustakaan seperti peraturan perundangundangan dan sumber lain yang relevan. Penelitian ini meneliti kriteria merek terkenal dengan melakukan perbandingan antara hukum yang ada di Indonesia dengan negara-negara serta meneliti mengenai upaya hukum apa saja yang dapat ditempuh jika terjadi pelanggaran. Hasil dari penelitian ini yaitu ada beberapa kriteria merek terkenal yang dapat diterapkan di Indonesia dari peraturan negaranegara lain untuk memberikan kepastian hukum. Beberapa kriteria tersebut adalah catatan keberhasilan penggunaan merek, merek telah terdaftar di berbagai negara, dan yang belum ada di sistem hukum Indonesia yaitu pendaftaran khusus merek terkenal. Untuk upaya hukum terhadap pelanggaran merek terkenal dapat melalui dalam pengadilan (litigasi) atau dapat melalui luar pengadilan (non litigasi) seperti penyelesaian sengketa melalui arbitrase.

\section{Abstract}

International trademark regulation is based on the Paris Convention and The Agreement on Trade-Related Aspects of Intellectual Property Rights (TRIPS) while in 


\title{
Jurnal Cakrawala Hukum, Volume 12 No. 1 April 2021
}

ISSN PRINT 2356-4962 ISSN ONLINE 2598-6538

\begin{abstract}
Indonesia the regulation regarding trademark has undergone several changes, most recently Law Number 20 of 2016 concerning Trademarks and Geographical Indication. A trademark can be said to be a well-known trademark if it meets the criteria for a well-known trademark, but the latest Indonesia trademark law does not clearly explain the criteria for it. This study uses a normative juridical approach. This approach focuses on examining literature materials such as legislation and other relevant sources. This study examines the criteria for a well-known trademark by making comparisons between existing laws in Indonesia and countries and examines what legal remedies can be taken if a violation occurs. The results of this study indicate that there are several criteria for a well-known trademark that can be applied in Indonesia from the regulations of other countries to provide legal certainty. Some of these criteria are records of successful use of marks, trademarks that have been registered in various countries and those that are not yet in the Indonesian legal system, namely special registration of a well-known trademark. For legal measures against infringement of the well-known trademark, it can be done in court (litigation) or outside the court (nonlitigation) such as dispute resolution through arbitration.
\end{abstract}

\section{Latar Belakang}

Isu mengenai merek di Indonesia terus berkembang dari waktu ke waktu dikarenakan cara berpikir manusia yang semakin kreatif. Hal ini seiring dengan kreativitas akan terus mengalami pembaharuan jika orang yang kreatif tersebut mendapat keuntungan sesuai dengan dasar teori dari rezim kekayaan. Oleh karena itu pemikiran mengenai ide kreatif dalam kekayaan intelektual sudah sewajarnya dilindungi oleh negara melalui peraturan perundang-undangan.

Merek terus berkembang dalam dunia perdagangan dan industri dikarenakan fungsi dari merek itu sendiri yaitu menjadi tanda pengenal atas keunikan produk yang dihasilkan oleh seseorang. Selain fungsi pembeda, merek juga berfungsi sebagai sarana promosi suatu produk. Oleh karena itu merek ini merupakan bagian dari kekayaan intelektual yang besar peranannya terhadap sebuah produk seperti halnya hak cipta dan paten (Sulastri, 2018).

Indonesia sangat memperhatikan mengenai dalam melindungi merek yang bagian dari kekayaan intelektual yang dilindungi (Kusuma, \& Sugama, 2020). Sama halnya seperti paten dan hak cipta serta kekayaan intelektual lainnya, merek juga merupakan bagian yang tidak terpisahkan dari kekayaan intelektual. Selain itu merek juga disebutkan secara eksplisit dalam kosideran Undang-Undang Nomor 20 Tahun 2016 tentang Merek dan Indikasi Geografis (selanjutnya disebut UU MIG) bagian menimbang butir a yang pada intinya menyatakan bahwa peranan merek sangat penting dalam menjaga persaingan usaha yang sehat dan terhadap perlindungan konsumen itu sendiri.

UU MIG bagian menimbang butir a membuktikan bahwa Indonesia sangat peduli dalam perlindungan kekayaan intelektual. Hal ini dikarenakan merek menunjang performa perkembangan ekonomi di negara Indonesia. Merek tersebut negara mendapat suatu keuntungan atau penghasilan yang dinamakan sebagai Penerimaan Negara Bukan Pajak (PNBP).

Merek akan berubah status menjadi hak atas merek yang memiliki kepastian hukum. Hal ini terjadi jika merek yang dimiliki di daftarkan ke Direktorat Jenderal Kekayaan Intelektual (selanjutnya disebut DJKI). Dengan maksud menghindari persaingan usaha yang tidak sehat, contohnya pembajakan, pemalsuan, atau bahkan peniruan ter- 


\section{Kajian yuridis tentang merek terkenal dan upaya hukum terhadap pelanggarannya}

Kevien Dicky Aldison, Sunarjo, Hendra Djaja

hadap merek tersebut sehingga pendaftaran akan menjaga dan menjamin originalitas atau keasliannya. Dengan adanya merek yang memiliki status sebagai hak atas merek jika sudah didaftarkan, maka suatu merek tersebut akan memiliki payung hukum.

Hak memiliki atas merek, seseorang atau perusahaan harus mendaftarkan mereknya ke DJKI dengan memenuhi dan memperhatikan bahwa mereknya ada daya pembeda. Jika tidak ada daya pembeda maka pendaftaran merek tersebut akan ditolak. Kemudian, pendaftaran merek juga dapat ditolak jika terdapat merek yang sudah terdaftar atau pun merek terkenal. Unsur memiliki persamaan merek terkenal menjadi pembahasan yang menarik dikarenakan merek terkenal belum secara rinci dijelaskan di dalam UU MIG. Bahkan pengertian merek terkenal tidak ada dijelaskan di pasal ketentuan umum UU MIG.

Merek terkenal belum secara pasti mengenai dasar payung hukumnya di UU MIG. Hal ini sangat berdampak pada perlindungan merek itu sendiri di mana pada akhirnya sulit untuk melindungi merek ini dari tindakan-tindakan yang melanggar. Tidak heran banyak sengketa di pengadilan yang berkaitan dengan merek terkenal.

Salah satu sengketa merek terkenal yang menjadi perbincangan di Indonesia adalah sengketa merek "Superman". Sengketa ini melibatkan DC Comics dengan PT. Marxing Fam Makmur, di mana permasalahan ini berlanjut hingga naik ke meja hijau pengadilan dengan nomor register perkara No. 1105 K/Pdt.Sus-HKI/ 2018. DC Comics merupakan perusahaan yang memiliki reputasi di dunia yang menerbitkan beberapa karakter atau tokoh manusia super melalui sebuah komik yang berpusat di negara Amerika Serikat. Sedangkan PT. Marxing Fam Makmur adalah perusahaan yang menjual berbagai macam makanan ringan yang berpusat di kota Surabaya. Salah satu produknya adalah wafer "Superman" yang sangat melegenda di seluruh pelo- sok Indonesia (Detik News, 2019).

Perselisihan antara DC Comics dan PT. Marxing Fam Makmur ini di awali ketika DC Comics mencoba mendaftar mereknya ke DJKI sekitar pada tahun 2017 terkhususnya merek "Superman". Merek "Superman" yang dimaksud ini adalah logo yang berbentuk "S" dan "Lukisan berbentuk karakter Superman". Kemudian pendaftaran itu ditolak diakibatkan sudah ada pemegang hak atas merek tersebut yaitu PT. Marxing Fam Makmur yang telah mendaftarkannya pada tahun 1993 ke Kementerian Hukum dan Hak Asasi Manusia.

DC Comics tidak menerima penolakan tersebut kemudian mengajukan gugatan ke Pengadilan Niaga di Pengadilan Negeri Jakarta. Dengan dalil bahwa merek "Superman" merupakan hak eksklusif DC Comics yang sudah diakui diseluruh pelosok dunia sebagai suatu merek terkenal. Kemudian meminta pengadilan menyatakan bahwa merek "Superman" atas nama PT. Marxing Fam Makmur telah didaftarkan dengan memiliki persamaan dengan merek terkenal dari DC Comics. Tetapi hakim pada Pengadilan Negeri Jakarta menolak gugatan dari DC Comics tersebut begitu pula pada tingkat kasasi hakim Mahkamah Agung juga menolak gugatan DC Comics, sehingga timbul pertanyaan ada kekaburan hukum atas kriteria merek terkenal yang ada UU MIG jika dilihat merek DC Comics yang sudah terkenal secara internasional saja bisa ditolak pendaftarannya.

Sengketa lain yang memiliki kaitan dengna merek terkenal selain merek "superman" yang sampai ke pengadilan dengan nomor register perkara 30/Pdt.Sus-Merek/2018/PN. Niaga Jkt.Pst. adalah merek yang dimiliki oleh Nissan Motor, Co.Ltd. dengan merek yang dimiliki oleh PT. Sekawan Niaga Mustika Alam. Merek yang dipermasalahkan adalah merek "infiniti" milik Nissan Motor, Co.Ltd. dan "infinity" milik PT. Sekawan Niaga Mustika Alam. Permasalahan ini dimulai pada saat Nissan Motor, Co.Ltd. mengecek daftar merek terdaftar di PDKI di mana menemukan merek yang 
sudah terdaftar tetapi memiliki persamaan pada pokoknya dengan milik Nissan Motor, Co.Ltd.

Nissan Motor, Co.Ltd. tidak menerima ada merek yang memiliki persamaan pada pokoknya dengan merek mereka dapat menjalankan perdagangan sehingga Nissan Motor PT. Sekawan Niaga Mustika Alam serta Direktorat Jenderal Kekayaan Intelektual (DJKI) ke pengadilan, sehingga dalam putusannya pengadilan menghapuskan merek "infinity" dari daftar merek di PDKI. Hal ini menyebabkan pertanyaan lebih lanjut bagaimana Direktorat Jenderal Kekayaan Intelektual (DJKI) dalam menilai persyaratan-persayaratan yang diajukan oleh pendaftar merek di mana apakah memenuhi unsur persamaan pada pokoknya atau tidak.

Beranjak dari uraian dan permasalahan-permasalahan di atas, penulis menemukan norma kabur (vague van normen) atas Pasal 21 ayat (1) huruf b dan c UU MIG berkaitan dengan persamaan pada pokoknya dengan merek terkenal. Dalam ketentuan umum Pasal 1 tidak dijelaskan mengenai pengertian persamaan pada pokoknya kemudian penjelasan Pasal 21 ayat (1) huruf b dan c UU MIG tidak ada disebutkan secara detail mengenai ruang lingkup persamaan pada pokoknya dengan merek terkenal Kondisi ini singkatnya ada suatu aturan tetapi aturan tersebut tidak jelas dan mimilik banyak penafsirannya. Permasalahan yang dibahas yaitu mengenai kriteria merek terkenal dan upaya hukum terhadap pelanggaran merek terkenal.

\section{Metode}

Jenis penelitian yang digunakan adalah penelitian hukum yuridis-normatif. Penelitian berfokus pada konsep atau perkembangan atas dasar doktrin yang dianut oleh pembuat konsep dan/atau pembuat perkembangan (Wignjosoebroto, 2002). Secara khusus penelitian ini akan berfokus meneliti kata merek terkenal dalam pasal 21 ayat 1 huruf $b$ dan c UU MIG.
Pendekatan masalah yang digunakan dalam penelitian ini adalah pendekatan perundangundangan (statute approach), pendekatan konsep (conceptual approach), pendekatan sejarah (historical approach), dan pendekatan perbandingan (comparative approach).

\section{Pembahasan}

\subsection{Kriteria merek terkenal}

World Intellectual Property Organization (selanjutnya disebut WIPO) juga mengeluarkan produk hukum yang secara khusus mengatur mengenai kriteria merek terkenal di mana pengaturan ini dinamai Joint Recommendation Concerning Provisions on the Protection of Well-Known Marks yang mana ada beberapa kriteria merek dapat terkenal yaitu: 1. Tingkat pengetahuan merek di masyarakat; 2. Durasi dan luas wilayah penggunaan merek; 3. Jangkauan geografis dari setiap promosi barang atau jasa yang menggunakan merek; 4. Jangkauan geografis dari setiap pendaftaran merek yang mencerminkan pengakuan merek; 5. Catatan keberhasilan dalam mempertahankan kepemilikan merek; 6 . Merek yang bernilai.

Selain pengaturan merek terkenal di keluarkan oleh WIPO, di Amerika Serikat juga ada pengaturan mengenai kriteria merek terkenal yang ada dalam Trademark Dilution Revision Act of 2006. Dalam aturan ini merek dapat terkenal jika secara luas diakui oleh konsumsi umum publik sebagai sebutan sumber barang atau jasa merek pemilik. Dalam menentukan apakah suatu merek memiliki tingkat pengakuan yang diperlukan, pengadilan dapat pertimbangkan semua faktor yang relevan yang pada intinya, yaitu: 1. Durasi, jangkauan, dan sebaran geografis dari iklan dan publisitas merek, baik diiklankan atau dipublikasikan oleh pemilik atau pihak ketiga; 2. Jumlah, volume, dan geografisnya sejauh mana penjualan barang atau jasa yang ditawarkan dengan menggunakan merek; 3 . Tingkat pengakuan aktual atas merek. 


\section{Kajian yuridis tentang merek terkenal dan upaya hukum terhadap pelanggarannya \\ Kevien Dicky Aldison, Sunarjo, Hendra Djaja}

Negara selain Amerika Serikat yang mengatur mengenai kriteria merek terkenal adalah Singapura. Di Singapura pengaturan kriteria merek terkenal diatur dalam Trade Marks Act 2005 Kriteria merek terkenal yang dimaksud yang pada intinya adalah (Singapore Statutes Online, 2005): 1. Sejauh mana merek tersebut dikenal atau diakui oleh sektor publik yang relevan di Singapura; 2. Wilayah, durasi, dan luas: a. Setiap merek yang digunakan; atau $\mathrm{b}$. Promosi barang atau jasa yang menggunakan merek; 3.Setiap pendaftaran merek di berbagai negara dimana tempat penjualan barang atau jasa; 4. Catatan keberhasilan dalam mempertahankan kepemilikan merek; 5. Merek bernilai; 6. Merek tersebut dikenal oleh masyrakat Singapura.

Jauh sebelum Amerika Serikat dan Singapura mengeluarkan pengaturan mengenai kriteria merek terkenal, India lebih dahulu mengeluarkan produk hukum yang dinamai The Trademark Art pada tahun 1999. Pengaturan ini memuat mengenai beberapa kriteria merek terkenal yaitu meliputi (Office of Controller General Patent, Design, Trade Mark, Department for Promotion of Industry and Internal Trade Ministry of Commerce E Industry, Government India, 1999): 1. Merek dikenal oleh masyarakat India; 2. Penggunaan merek yang tersebar luas; 3. Promosi barang atau jasa yang menggunakan merek; 4. Setiap pendaftaran merek di berbagai negara dimana tempat penjualan barang atau jasa; 5. Catatan keberhasilan dalam mempertahankan kepemilikan merek.

Sekilas pengaturan mengenai merek terkenal dari India yang dinamakan Trade Marks Act 2005 dengan pengaturan merek terkenal dari Amerika Serikat yang dinamakan Trademark Dilution Revision Act of 2006 hampir tidak memiliki perbedaan. Walaupun begitu pengaturan mengenai merek tekenal dari India ini mengeluarkan pengaturan yang lebih kongkrit mengenai merek dapat dikatakan terkenal yaitu ada pada Trademark Rules 2017 pemilik merek dapat langsung mengajukan permohonan merek terkenal ke pengadilan. Permohonan pen- daftaran tersebut harus disertai dengan dokumen yang relevan kriteria-kriteria merek terkenal yang ada Trade Marks Act 2005 dan membayar biaya pendaftaran. Dengan adanya pengaturan ini merek terkenal bukan hanya julukan tetapi memiliki legal standing yang kuat dan sah.

Pengaturan di Indonesia sendiri mengenai merek terkenal memang sangat jarang muncul dalam pembahasan padahal merek terkenal merupakan aset yang sangat berharga bagi suatu pihak. Lampu terang mengenai definisi merek terkenal baru ada ketika dikeluarkannya Keputusan Menteri RI No.M.03-HC.02.01 Tahun 1991 tentang Penolakan Permohonan Pendaftaran Merek Terkenal Milik Orang Lain atau Milik Badan Lain yang mencoba mendefinisikan secara terkodifikasi di dalam pasal 1 yang pada intinya bermakna bahwa merek terkenal merupakan merek dikenal dan diperdagangkan baik di Indonesia maupun di luar Indonesia. Setelah dikeluarkannya Keputusan mengenai merek terkenal, Mahkamah Agung kemudian mengeluarkan yurisprudensi yaitu Yurisprudensi Mahkamah Agung Nomor 1486K/Pdt/1991 yang pada intinya merek dapat terkenal jika sudah penjualan barang atau jasa yang sudah tersebar luas dan pendaftarannya sudah di beberapa negara.

Yurisprudensi Mahkamah Agung Nomor 1486K/Pdt/1991, merupakan pembaharuan pengaturan merek seperti Undang Undang Nomor 14 Tahun 1997 tentang Merek (UU Merek lama) dan Undang Undang Nomor 14 Tahun 1997 (UU Merek lama) tentang Merek belum mengatur mengenai merek terkenal lebih lanjut dikarenakan lebih fokus pada perbaikan sistem pendaftaran merek. Merek terkenal mulai diatur kembali dengan yurisprudensi kedua mengenai kriteria merek terkenal dikarenakan banyaknya sengketa dan opini mengenai merek terkenal. Yurisprudensi ini dinamakan Yurisprudensi Tetap Mahkamah Agung Rl Nomor 022 K/HaKI/2002 tanggal 20 Desember 2002. Dalam yurisprudensi ini memuat kriteria-kriteria merek terkenal yang pada intinya yaitu: 1 . 


\section{Jurnal Cakrawala Hukum, Volume 12 No. 1 April 2021}

ISSN PRINT 2356-4962 ISSN ONLINE 2598-6538

Pengetahuan masyarakat atas merek sangat tinggi; 2. Promosi yang besar membuat merek menjadi memiliki reputasi tinggi di berbagai negara; 3 . Di berbagai negara ada bukti pendaftaran merek.

Berdasarkan yurisprudensi di atas memang terlihat sulit untuk mendapatkan jawabkan atas kriteria merek terkenal dikarenakan masih sangat abstrak mengenai kriterianya itu sendiri. Sebetulnya selain yurispridensi ini dalam UndangUndang No. 15 Tahun 2001 Tentang Merek (UU Merek lama) yang diperbaharui dalam UU MIG mencoba memberikan limitasi dari merek terkenal itu sendiri. Di penjelasan UU Merek lama maupun UU MIG, kriteria terkenal terbatas pada pengetahuan umum yang menjadi tolak ukur kriteria merek terkenal. Tentunya, pengetahuan umum ini sangat abstrak maknanya.

Analisis lebih mendalam berkaitan dengan yurisprudensi Tetap Mahkamah Agung Rl Nomor 022 K/HaKI/ 2002 tanggal 20 Desember 2002 dan UU Merek lama serta UU MIG masih sebatas abstrak mengatur mengenai merek terkenal. Hal ini dapat dilihat dari limitasi yang diberikan untuk merek terkenal yang hanya sebatas kata-kata tanpa ada angka atau nominal pasti apa yang harus dicapai untuk menjadi merek terkenal.

UU Merek lama serta UU MIG masih belum dapat menjelaskan kriteria khusus mengenai merek terkenal sehingga Menteri Hukum dan Hak Asasi Manusia membuat peraturan khusus yang di dalamnya mengatur mengenai kriteria merek terkenal. Peraturan ini dinamai dengan nama Peraturan Menteri Hukum dan Hak Asasi Manusia Nomor 67 Tahun 2016 tentang Pendaftaran Merek. Pada pasal 18 ayat (3) menyatakan ada beberapa kriteria merek terkenel yang pada intinya yaitu; a. Merek sudah dianggap sebagai merekt terkenal oleh masyarakat; $\mathrm{b}$. Tingginya keuntungan oleh penjualan barang dan/atau jasa yang di labeli merek; c. Merek sebagai penguasa atas pangsa pasar yang penyebarannya luas; d. Penggunaan merek yang luas; e. Merek yang digunakan sudah berjalanan dalam waktu tertentu; f. Tingginya tingkat promosi merek; g. Pendafataran merek di berbagai negara; h. Catatan keberhasilan dalam mempertahankan kepemilikan merek; atau i. Merek yang melekat pada barang dan/atau jasa memiliki jaminan kualitas.

Analisa terhadap bagaimana kriteria mengenai merek terkenal yang ada di Indonesia memunculkan pendapat bahwa pendaftaran merek terkenal seperti yang ada di sistem hukum India sangat menarik untuk Indonesia terapkan dalam sistem hukum Indonesia. Di Indonesia sendiri masih belum ada pendaftaran merek terkenal secara khusus untuk mendapat legal standing melainkan hanya pendaftaran merek biasa. Mengikuti metode sistem hukum yang dikemukakan oleh India ini berpengaruh positif dalam mengurangi sengketa merek terkenal yang terjadi di Indonesia karena ada suatu kepastian hukum dalam mengukur merek terkenal tersebut.

Selain beberapa pengaturan mengenai kriteria merek terkenal baik itu secara internasional maupun nasional, ada beberapa sarjana yang mencoba mengungkapkan kriteria merek terkenal. Menurut Insane Budi Maulana dan T. Mulya Lubis di dalam buku yang ditulis oleh Leden Marpaung menyatakan ada 3 kriteria merek terkenal yaitu (Marpaung, 1995): 1. Dalam dan luar negeri merek tersebut sudah didaftarkan; 2. Penggunaan merek tersebut di berbagai negara; 3. Masyarakat luas mengenal merek terebut.

M. Yahya Harahap sebagai salah satu pakar hukum perdata di Indonesia juga mencoba memberikan pendapat mengenai apa saja kriteria merek dapat dikatakan terkenal yaitu (Harahap, 1992): 1. Konsumen secara luas menjadikan merek tersebut sebagai idaman; 2 . Lambang suatu merek menjadi daya tarik pencarian; 3. Faktor-faktor pendukung lainnya yaitu: a. Nilai pemasaran secara presentasi tinggi; b. Presentasi yang dimaksud harus memiliki keterkaitan dengan luasnya wilayah pemasaran secara internasional; c. Stabilnya pen- 


\section{Kajian yuridis tentang merek terkenal dan upaya hukum terhadap pelanggarannya}

Kevien Dicky Aldison, Sunarjo, Hendra Diaja

dapatan dan kegiatanan usaha dalam waktu tertentu; d. Kelas atau jenis barang menjadi pertimbangan.

Setelah melihat, membaca, memeriksa, menelaah dan menafsirkan beberapa kriteria merek terkenal dari beberapa sumber yang telah diungkapkan di penelitian ini maka ada suatu pendapat yang muncul dari penulis mengenai apa saja kriteria merek dapat terkenal. Beberapa kriteria merek terkenal tersebut adalah: 1. Catatan keberhasilan dalam pemasaran suatu barang atau jasa menggunakan suatu merek; 2. Promosi suatu barang atau jasa menggunakan merek yang gencargencar dengan media apa pun; 3. Pendapat yang besar dari hasil penjualan barang atau jasa menggunakan merek tersebut stabil dalam waktu yang lama; 4. Barang atau jasa yang dipasarkan menggunakan merek tersebut menjadi idaman bagi masyarakat; 5 . Penjualan barang atau jasa menggunakan merek tersebut tidak hanya di dalam negeri tetapi juga di luar negeri; 6. Didaftarkan sebagai merek terkenal ke lembaga terkait.

Kriteria yang diungkapkan oleh lembaga kekayaan intelektual secara internasional maupun nasional, kemudian pengaturan kriteria merek terkenal yang berasal dari Amerika Serikat, Singapura, India dan Indonesia, beberapa pendapat sarjana serta pendapat dari penulis sendiri, ada satu hal yang pasti ada kriteria merek dapat dikatakan terkenal yaitu tingkat pengetahuan masyarakat atas merek tersebut yang dibuktikan dengan catatan keberhasilannya.

\subsection{Upaya hukum terhadap pelanggaran merek terkenal}

Upaya hukum terhadap pelanggaran merek terkenal di Indonesia juga ada. Hal ini juga berkaitan dengan amanat dari hukum internasional baik itu dari Konvensi Paris ataupun TRIPS yang memberikan wewenangan untuk menyelesaikan sengketa sesuai dengan dasar dari teori delegasi.
Upaya hukum di Indonesia diatur dalam UU MIG. Upaya hukum yang dapat ditempuh oleh para pemilik merek terkenal jika terjadi pelanggaran sesuai dengan UU MIG adalah dengan cara litigasi atau biasa disebut jalur melalui pengadilan serta jalur non litigasi atau biasa diartikan sebagai upaya hukum di luar pengadilan.

\section{Upaya hukum di dalam pengadilan (secara litigasi)}

Upaya hukum melalui jalur litigasi dibagi menjadi jalur pidana maupun perdata. Secara perdata penyelesaian sengketa merek diatur dalam pasal 76 UU MIG yaitu yang pada intinya dapat mengajukan permohonan pembatalan merek, sehingga menjadi dasar kuat untuk mengajukan gugatan ke Pengadilan Niaga yang berwenang menyelesaikan sengketa merek terkenal. Gugatan dapat dilakukan walaupun merek terkenal tersebut sudah terdaftar ataupun belum terdaftar di Indonesia.

Isi dari gugatan berupa meminta ganti rugi dan/atau penghentian semua perbuatan yang berkaitan dengan penggunaan merek tersebut sesuai pasal pasal 83 UU MIG. Dua hal yang menjadi permintaan ini akan dapat dieksekusi pada saat Pengadilan Niaga telah mengeluarkan putusan. Jika para pihak yang bersengketa tidak puas dengan putusan yang di keluarkan oleh Pengadilan Niaga maka dapat mengajukan upaya hukum kasasi serta jika belum puas juga dengan hasil putusan kasasi maka dapat mengajukan upaya hukum peninjauan kembali ke Mahkamah Agung.

Upaya hukum litigasi secara perdata ini merupakan langkah upaya hukum yang paling sering digunakan oleh para pihak yang merasa merek terkenal mereka dilanggar oleh para pihak yang sengaja yang menimbulkan kerugian. Oleh karena itu upaya hukum ini harus dipahami sesuai dengan ketentuan yang ada di dalam UU MIG. Agar supaya tidak mengalami cacat formil atau cacat materiil. 


\section{Jurnal Cakrawala Hukum, Volume 12 No. 1 April 2021}

ISSN PRINT 2356-4962 ISSN ONLINE 2598-6538

Selain upaya hukum litigasi secara perdata pemilik merek terkenal juga dapat mengajukan upaya hukum litigasi secara pidana. Upaya hukum yang dimaksud yaitu dengan melaporan pelanggaran terhadap merek terkenal kepada pihak kepolisian. Tentunya pelanggaran atas merek terkenal ini berlaku delik aduan di mana penyidikan oleh Polisi Republik Indonesia akan dapat dilakukan jika pihak yang dirugikan dalam hak ini pemilik merek terkenal melaporkan pelanggaran tersebut sesuai dengan ketentuan yang ada pada pasal 103 UU MIG.

Upaya hukum melalui pengadilan (litigasi) baik itu secara perdata maupun pidana merupakan upaya yang biasa dilakukan oleh para pihak terkhususnya pemilik merek terkenal jika terjadi pelanggaran. Upaya hukum litigasi ini memang merupakan upaya hukum yang cukup lama dalam hal penyelesaiannya tetapi kepastian hukum dan kekuatan pembuktiannya sangat tajam dan terukur untuk mendekati kebenaran yang sebenar-benarnya.

\section{Upaya hukum di luar pengadilan (secara non litigasi)}

Upaya hukum yang tempuh melalui jalur non litigasi atau di luar pengadilan ini merupakan bisa melalui arbitrase atau melalui penyelesaian sengketa alternatif sesuai dengan ketentuan yang ada di pasal 93 UU MIG. Berdasarkan pasal 1 angka 1 Undang-Undang Nomor 30 Tahun 1999 tentang Arbitrase dan Alternatif Penyelesaian Sengketa, arbitrase pada intinya bermakna penyelesaian sengketa diluar pengadilan yang berujung pada perjanjian tertulis.

Para pihak yang bersengketa harus sepakat terlebih dahulu untuk menyelesaikan sengketanya sedang dialami agar diselesaikan melewati arbitrase melalui perjanjian tertulis yang disetujui oleh para pihak (Winarta, 2016). Terdapat dua metode dalam upaya hukum melalui jalur arbitrase yang dapat digunakan para pihak dalam menyelesaikan sengketanya yaitu Arbitrase ad hoc dan Arbitrase institusional.

Arbitrase ad hoc pihak-pihak yang bersengketa bisa menentukan sendiri bagaimana pelaksanaan dalam pemilihan arbiter, konteks kerja prosedur arbitrase, dan aparatur bagian adiministrasi dari arbitrase. Penentuan ini dikarenakan dalam prosesnya tanpa ada pengawasan atau peninjauan yang bersifat kelembagaan. Arbitrase ad hoc ini memiliki sifat yang sewaktu-waktu atau berjangka sampai pada sengketa yang diputuskan (Salam, 2007). Ada beberapa kelemahan dalam pelaksaan arbitrase ad hoc yaitu kesulitan menetapkan aturan proseduran dari aribtrase, kemudian kesulitan dalam merencanakan metode pemilihan arbiter yang bisa disetujui para pihak, serta kesulitan melaksanaan negosiasi (Salam, 2007).

Perbedaan mendasar antara arbitrase ad hoc dan arbitrase instutisional terletak tidak terkoordinasi dan terkoordinasi. Arbitrase ad hoc merupakan cara penyelesaian yang tidak terkoordinasi oleh suatu lembaga sedangkan arbitrase institusional merupakan cara penyelesaian yang terkoordinasi oleh suatu lembaga (Usman, 2013). Arbitrase institusional ini merupakan lembaga yang didirikan oleh lembaga tertentu untuk menampung sengketa-sengketa yang biasanya berasal dari suatu perjanjian. Arbitrase institusional ini bersifat permanen juga disebut permanent arbitral body di mana di dalam pendiriannya memang sengaja didirikan. Yang dimaksude dengan permanen disini berarti bahwa arbitrase intitusional ini sudah ada sebelum adanya sengketa dan akan tetap ada walaupun sengketa telah selesai.

Penyelesaian sengketa merek terkenal melalui jalur arbitrase yang sesuai dan dapat ditempuh oleh pihak yang dirugikan adalah arbitrase institusional. Hal ini dikarenakan penyelesaian sengketa melalui arbitrase institusional akan lebih terarah hasil dari penyelesaian sengketa tersebut dari pada aribtrase ad hoc yang tidak terkoordinasi. 


\section{Kajian yuridis tentang merek terkenal dan upaya hukum terhadap pelanggarannya \\ Kevien Dicky Aldison, Sunarjo, Hendra Diaja}

Penyelesaian sengketa merek terkenal melalui arbitrase institusional, lembaganya adalah Badan Arbitrase dan Mediasi Hak Keakayaan Intelektual. Lembaga ini dapat menyelesaikan sengketa merek terkenal diakrenakan merek terkenal merupakan bagian dari kekayaan intelektual. Badan Arbitrase dan Mediasi Hak Keakayaan Intelektual didirikan pada tahun 2012 yang kantornya berkedudukan di Jakarta.

Penyelesaian sengketa merek terkenal sebagai upaya hukum di Indonesia dengan ditandai beberapa kasus yang terdapat Indonesia, jarang ada yang menyelesaikan permasalah melalui jalur damai. Hal ini dikarenakan para pihak yang bersengketa sama-sama memiliki keinginan untuk mempertahankan merek terkenal tersebut sebagai salah satu asset paling berharga bagi mereka. Upaya hukum yang dilakukan pemilik terkenal merupakan bentuk perlindungan atas asetnya sehingga baik upaya penyelesaian sengketa melalui litigasi maupun non litigasi dapat ditempuh sesuai peraturan perundang-undangan yang berlaku.

\section{Simpulan}

Setelah menelusuri dan mempelajari kriteria merek terkenal baik secara internasional maupun di Indonesia, merek dapat dikatakan terkenal dikarenakan beberapa hal yang pada intinya yaitu catatan keberhasilan produk yang dilabeli merek tersebut, promosi merek yang masif, pendapatan yang besar atas penggunaan merek, penjualan produk yang dilabeli merek tersebut ada di dalam dan di luar negeri. Selain lima kriteria merek terkenal tersebut, ada penambahkan kriteria yaitu pendaftaran merek terkenal secara khusus ke lembaga terkait agar merek terkenal tersebut secara sah dan resmi diakui sebagai merek terkenal.

Upaya hukum di Indonesia sendiri yang dapat di lakukan oleh pemilik merek terkenal jika terjadi pelanggaran diatur dalam UU MIG. Upaya hukum ini dapat ditempuh secara dalam pengadilan (litigasi) maupun luar pengadilan (non litigasi). Secara litigasi dapat mengajukan gugatan ganti rugi dan/atau pemberhentian penggunaan merek yang merugikan ataupun tuntutan pidana ke Pengadilan Niaga. Secara non litigasi maka dapat menyelesaikan sengketa merek terkenal di luar pengadilan dengan salah satu cara yaitu penyelesaian melalui arbitrase.

\section{DaftarPustaka}

Amrulla, M.F., 2018. Urgensi pengaturan tentang peralihan hak atas merek sebagai objek jaminan fidusia. Jurnal Cakrawala Hukum, 9(2), pp.135-141.

Djaja, H., 2013. Perlindungan Indikasi Geografis Pada Produk Lokal Dalam Sistem Perdagangan Internasional. Jurnal Cakrawala Hukum, 18(2).

Harahap, M. Yahya. 1997. Tinjauan Merek Secara Umum dan Hukum Merek di Indonesia Berdasarkan UndangUndang Nomor 19 Tahun 1992. Citra Aditya. Bandung.

Kusuma, Ida Ayu Sri Dewi, \& Sugama, I Dewa Gede Dana. 2020. Upaya arbitrase dalam penyelesaian sengketa Merek terkenal. Vol. 9, No. 3.

Marpaung, Leden. 1995. Tindak pidana terhadap hak atas kekayaan intelektual. Sinar Grafika. Jakarta.

Miladiyanto, S. and Ariyanti, A., 2020. Perinsip moralitas merek dalam undang-undang nomor 20 tahun 2016 tentang Merek dan Indikasi Geografis. Jurnal Cakrawala Hukum, 11(3).

Office of Controller General Patent, Design, Trade Mark, Department for Promotion of Industry and Internal Trade Ministry of Commerce \& Industry, Government India. 1999. The Trade Marks Act 1999. Government India. India.

Salam, Moch. Faisal. 2007. Penyelesaian sengketa bisnis secara nasional dan internasional. Mandar Maju. Bandung.

Singapore Statutes Online. Trade Marks Act 2005. diakses dari https://sso.agc.gov.sg/Act/TMA1998. diakses tanggal 9 November 2020.

Sulastri, dkk. 2018. Perlindungan hukum terhadap merek (tinjauan terhadap merek dagang Tupperware versus Tulipware. Jurnal Yuridis, Vol.5, No.1, Juni. 


\section{Jurnal Cakrawala Hukum, Volume 12 No. 1 April 2021}

ISSN PRINT 2356-4962 ISSN ONLINE 2598-6538

Tim Detik News, Bukan cuma superman, merek-merek top dunia ini juga keok di Indonesia (Online). diakses dari https://news.detik.com/berita/d-4569146/ bukan-cuma-superman-merek-merek-top-duniaini-juga-keok-di-indonesia. diakses pada tanggal 30 Maret 2020.

Usman, Rachmadi. 2013. Pilihan penyelesaian sengketa di luar pengadilan. Citra Aditya Bakti. Bandung.

Web Crunchbase. 2020. DC. Comics. diakses dari: https:/ / www.crunchbase.com/organization/dccomics\#section-overview, diakses pada tanggal 30 Maret 2020.
Wignjosoebroto, Soetandyo. 2002. Hukum: paradigma, metode, dan dinamika masalahnya. Elsem. Jakarta.

Winarta, Frans Hendra. 2016. Hukum Penyelesaian Sengketa Arbitrase Nasional Indonesia dan Internasional. Sinar Grafika Offset. Jakarta.

World Intellectual Property Organization (WIPO). 1999. Joint Recommendation Concerning Provisions on the Protection of Well-Known Marks. World Intellectual Property Organization, Paris. 